\title{
LVII. On certain researches of Murphy
}

\author{
James Cockle Esq. M.A.
}

To cite this article: James Cockle Esq. M.A. (1848) LVII. On certain researches of Murphy, Philosophical Magazine Series 3, 32:217, 421-422, DOI: 10.1080/14786444808646015

To link to this article: http://dx.doi.org/10.1080/14786444808646015

曲 Published online: 30 Apr 2009.

Submit your article to this journal

Џ Article views: 2

Q View related articles $₫$ 
The letter itself appears (from the folding) to have been placed in a cover, and there is no superscription or direction. Though, therefore, I have supposed that it was addressed to Nourse, I have no other ground for such an opinion than that it was found amongst a nass of letter's which were so addressed. My own impression is that Andrew Millar was the early publisher of Goldsmith's work, though I have no means of consulting a copy of a date antecedent to this letter. There are, at all events, no other letters to Millar amongst these : and the chief difficulty is to conjecture how a letter addressed to one publisher should get amongst those of his neighbour; especially as no very friendly feeling existed between the publisher's, nor much of sympathy between- the scientific an!l literary classes of that period.

Royal Military Academy,

February 15, 1848.

LVII. On certain Researches of Murphy. By J $\mathrm{J}_{\mathrm{AM}} \mathrm{Es}$ Cockle, Esq., M.A. of Trinity College, Cambridge, and Barrister-atLare of the Middle Temple*.

A $T$ page 129 of a memoir referred to below $t$, Murphy has given a rule by means of which we may express in the form of a series a root of any equation containing only positive and integer powers of the unknown quantity. In this memoir there is no allusion to any prior discovery of the rule; and Murphy subsequently $\ddagger$ refers to the process without mention of any other writer in connexion with it, and appears to regard himself as its originator. The rule seems to have been hitherto attributed to $\operatorname{him} \S$, and I have fallen into the same error at puge 363 of the present volume of this Journaly. It

- Communicated by the Author.

+ On the Resolution of Algebraic Equations. Published at pp. 126-153 of vol. iv. of the Transactions of the Cambridge Philosophical Society. See more particularly section $I, p p .129-133$.

‡ Camb. Phil. Trans., vol. iv. p. 355. See also Murphy's Theory of Equations, p. 77 , commencement of article $(62$.$) . It is to this article$ (pp. 77-89) of Murphy's work that I ought to have made reference supra, page 363 .

$\S$ See Dr. Peacock's Report on Analysis (to the British Association, Meeting of 1833), p. 350 .

II Among the defects of my paper here referred to, are the having omitted to make mention of the naine of Vandermonde, the great rival of Lagrange in the department of science there discussed, and also of Simpson's (subsidiary) and Professor J. R. Young's (indirect) solution of a biquadratic. And Mr. Davies has requested me to say, that from the haste with which his notes on my paper were written, he omitted to refer to a very neat and elegant 
will however be found that Lagrange had long before arrived at the same result. In his memoir cited below*, the last-mentioned illustrious analyst expresses the root of such an equation as that above alluded to by means of the same (logarithmic) process as that employed in the derivation of the rule of Murphy. Although the results of Lagrange and Murphy are identical, yet the great fame of the latter philosopher is fixed upon too sure a basis to be in the slightest degree shaken, even when we shall have restored this discovery to him to whom it is justly due. This is not the place to dwell on the relative hengths to which those two analysts have pushed their researches in this direction. I may observe, that my attention was attracted to the memoir of Lagrange by seeing it referred to by Garnier at page 355 of his Analyse (Paris; 1814), but my leaving town on circuit and other circumstances prevented me from noticing it till now.

2 Church-Yard Court, Temple, May $13,1848$.

LVIII. Abstract of Meteorological Observations made during the year 1847 at Gongo Soco, in the interior of Brazil. By William Jory Henwood, F.R.S., F.G.S., Member of the Geological Society of France, Chief Commissioner of the Gold Mines of Gongo Soco and Bananal, \&c. \&c.†

THE instruments, their situations, and the hours of obser1 vation have been the same as in former years $\ddagger$; and $I$ have again to thank Captains Blaney, Pengilly, Luke and Guy, for the results obtained at midnight and at 3 A.M.

exposition of Horner's method by Mr. Peter Gray, printed in the Mechanics' Magazine for March 1844. Mr. Davies also requests me to state, that a paper sent to the Royal Society in 1823 by Mr. Horner himself, has been printed in the Mathematician, vols. i. and ii.; a paper to which Mr. Davies considers it important to direct the attention of every one who takes interest in the prablem of the numerical solution of algebraic equations.

* Nouvelle Méthode pour résoudre les équations littérales par le moyen des séries. Par Mr. de la Grange. Published in the Berlin Memoirs for 1768, pp. 251-326. See the seventh article, pp. 261-263.

+ Communicated by the Author.

$\ddagger$ Phil. Mag. 1846, xxviii. pp. 364, 366 . 